\title{
POSTPRINT
}

Kerstin Schwabe

Werner Frey

André Meinunger

\section{Sentential proforms}

\section{An overview*}

\section{The outset}

Sentential proforms as shown in (1a-d) have been discussed intensely since they touch upon the crucial question of where embedded clauses are located and how they are licensed.

(1) a. Max hat (es) bedauert, dass Lea krank war.

Max has it regretted that Lea ill was

'Max regretted that Lea was ill.'

b. Max hat (es) bedauert, wenn Lea krank war.

Max has it regretted if Lea ill was

'Max regretted if Lea was ill.'

c. Max hat sich (darüber) gefreut,

Max has REFL.ACC d-about enjoyed

dass Lea wieder gesund war.

that Lea again well was

'Max was glad about the fact that Lea was well again.'

d. Max hat sich (dann) gefreut, wenn Lea gesund war.

Max has REFL.ACC then enjoyed if Lea well was

'Max was glad only then when Lea was well'.

They constitute an interface phenomenon in that their occurrence is determined not only syntactically but also prosodically and semantically.

Indeed, sentential proforms are not only found in German. They also appear in numerous other languages, as for instance in Slavic languages (cf. Zimmermann 1983, 2002), in English (cf. Huddleston \& Pullum 2002), and in Hungarian (cf. Brandtler \& Molnár this volume).

* This work was supported by the German Bundesministerium für Bildung und Forschung (BMBF) (Grant Nr. 01UG0711). 
As far as German grammar research is concerned, the sentential proform topic mainly plays a role when extraposition and topicalization are discussed (cf. Müller 1995; Haider 1994, 2010; Sternefeld 2006). Notes on sentential proforms can also be found in various grammar books, the most comprehensive one of them certainly being Zifonun, Hoffmann \& Strecker (1997).

There exist a few studies focusing on es-items, that is, pronoun es, positional $e s$, correlate es, etc. ${ }^{1}$ Here, one could mention Askedal (1985), Pütz (1986 ${ }^{2}$, Sandberg (1998), and Sudhoff (2003). Prepositional sentential proforms are extensively discussed in Breindl (1989).

At the Zentrum für Allgemeine Sprachwissenschaft (ZAS, Berlin) sentential proforms became a core issue when the ZAS-database on proposition embedding predicates was being compiled and ZAS researchers were studying extraposition and topicalization as well as left- and right-dislocation. In this context, interest evolved in creating a cluster of contemporary studies concentrating on sentential proforms and their related clauses. As a starting point, the workshop "Inner-sentential propositional correlates: Syntactic properties and interpretative effects" was organized. This workshop brought together various researchers. Some of them - Katrin Axel-Tober, Anke Holler and Helena Krause, Johan Brandtler and Valeria Molnár, Werner Frey, Kerstin Schwabe, Stefan Sudhoff, and Ilse Zimmermann - are contributors to this volume. In order to add prosodic expertise, Hubert Truckenbrodt was invited to take part in the sentential proform project. Andreas Nolda was asked to contribute because his work fits in well with the topic of prepositional sentential proforms.

This sentential proform volume mainly focuses on German es- and dasproforms as well as on prepositional proforms (ProPP). It discusses their form and their relationship to the clause they relate to.

German sentential proforms and, as will be shown by Sudhoff (this volume), Dutch ones are more or less regarded as nominal elements. The Hungarian azt seems to be similar to es. However Brandtler \& Molnár propose a new approach to this correlate-like element as being the spell-out of an edge feature.

Before introducing the individual contributions, a short overview of more or less recent previous approaches to the analysis of German es-and das-proforms as well of ProPPs will be given.

In the following, we use the spelling proform when the notion 'proform' relates pre-theoretically to all types of pronominal items that represent propositions. The spelling pro-form is used when the German referential es-pro-form is concerned.

1. For an overview of es-types, see Sudhoff (2003) and Zimmermann (this volume). 


\section{Recent approaches to sentential proforms and relating clauses}

\subsection{Es-proforms}

There exist various analyses of the German sentential proforms, either as individual analyses, such as, for instance, Buscha (1972), Askedal (1985), Pütz (1986²), Bærentzen (1987), Breindl (1989), Sonnenberg (1992), Sandberg (1998), and Sudhoff (2003), or as part of a broader topic, like, for instance, Zimmermann (1993), Büring \& Hartmann (1995), Haider (1995), Müller (1995), Müller \& Sternefeld (1993), Sternefeld (2006), Axel-Tober (2012), and Haider (2010). To name and to discuss all of them would go beyond the scope of this introduction.

The present collection of articles focuses on the es which relates to propositional entities, as for instance in the examples given in $(2 \mathrm{a}-\mathrm{c})$.

(2) a. Max bedauert es, dass Lea krank ist.

Max.NOM regrets it that Lea ill is

'Max regrets it that Lea is ill'.

b. Max amüsiert es, dass Lea tanzt.

Max.ACC amused it that Lea dances

'It amuses Max that Lea is dancing.'

c. Max behauptet es, dass Lea krank ist.

Max.Nom claims it that Lea ill is

'Max claims that Lea is ill.'

If one takes the sentences given in $(3 a-c)$ as all-focus answers, a crucial contrast becomes apparent.

(3) What's new? What happened?

a. Max bedauert es, dass Lea krank ist.

b. Max amüsiert es, dass Lea tanzt.

c. Max behauptet ( $\left.{ }^{*} e s\right)$, dass Lea krank ist.

This contrast points toward the assumption that the es in $(3 \mathrm{a}, \mathrm{b})$ is of an essentially different nature from the es in $(3 \mathrm{c})$. The pivotal observation goes back at least to the pioneering work by Pütz $\left(1986^{2}\right)$, and it has been translated into a modern version and elaborated by Sudhoff (2003; see also this volume). In ( $3 a, b)-$ as opposed to the occurrence of es in (3c) - the es lacks a referent in the previous discourse. To put it in Schwarzschild's (1999) words, it is focus marked. It relates cataphorically to the respective extraposed subject or object clause. Sudhoff refers to this es as correlate es. It is licensed by a particular class of predicates, namely by potentially factive predicates like bedauern 'regret' and by veridical predicates like erreichen 'achieve'.

As to the es in (3c), an overtly indicated proposition as in (4) is necessary. 
(4) Ist Lea krank?

is Lea ill

'Is Lea ill?'

Max behauptet es, (dass sie krank ist).

Max claims it that she ill is

'Max claims that she is ill.'

Sudhoff calls the es that refers to a preceding proposition an anaphoric pro-form. Predicates that license Sudhoff's correlate es can also co-occur with an anaphoric es, $(5 \mathrm{a}, \mathrm{b})$.

(5) a. Ist Lea krank?

is Lea ill

'Is Lea ill?'

Leider ist es wahr, dass sie krank ist.

unfortunately is it true that she ill is

'Unfortunately, it is true that she is ill.'

- see Sudhoff's similar example (35a)

b. Lea ist krank und Max bedauert es, dass sie krank ist. Lea is ill and Max regrets it that she ill is 'Lea is ill and Max regrets it that she is ill.'

The present volume discusses the question of to what extent it is legitimate to distinguish between the anaphoric pro-form es and correlate es and, perhaps, other sentential es-types.

The stance on the status of the es as being essentially the same or of a different nature plays an important role for the status of the relation between the proform and the associated clause. We call approaches that do not distinguish different lexical es-proforms 'uniform approaches'. Approaches that provide various es-items are referred to as 'hybrid approaches'.

\subsubsection{Hybrid approaches}

As shown above, Sudhoff (2003) - following observations by Pütz (1986 ${ }^{2}$ distinguishes two sentential es-types and, accordingly, two verb classes: the "correlate es," which is licensed by verbs like bedauern 'regret', and the "pro-form es," which is selected by verbs like behaupten 'claim'. Whereas bedauern-verbs allow the correlate es as well as the pro-form es, behaupten-verbs only license the pro-form es. Sudhoff's correlate es corresponds to Reis' (1997) expletive es. The bedauern-verbs have in common that they allow es and its related clause to be in one focus domain, $(3 \mathrm{a}, \mathrm{b})$. Behaupten-predicates, on the other hand, do not. Furthermore, Sudhoff points to the well-known observation that most of 
the behaupten-verbs license the embedding of verb second clauses in contrast to bedauern-verbs.

\subsubsection{Uniform approaches}

Most of the authors that do not differentiate between pro-form es and correlate es seem not to be conscious of the observation mentioned above that the es in all-focus contexts is restricted to particular matrix predicates - see, for instance, Müller (1995), Zifonun, Hoffmann \& Strecker (1997), Sternefeld (2006), and Haider (2010). Schwabe (2013) acknowledges the contrast between predicates licensing focus-marked es-items and predicates that do not. She proposes a uniform syntactic analysis where Sudhoff's es-correlate and anaphoric pro-form are both regarded as a propositional proform. The different behavior of Sudhoff's es-correlates and anaphoric pro-forms are aimed to be accounted for in semantics. The es is appropriate if it relates to a proposition given in the common ground as in (4) and (5) or if it contributes in creating an update for the ongoing discourse as in $(3 a, b)$. Conversely, it is inappropriate if it neither refers anaphorically nor contributes in creating an update, $(3 \mathrm{c})$.

\subsubsection{Relationship between es-items and relating clauses}

Müller (1995) regards an es-item as a nominal head which is the argument of the matrix predicate and the relating clause CP as an attribute of this argument, (6a). The relating clause can move to the right (extraposition), but cannot be topicalized. The topicalization is prevented by Müller \& Sternefeld's (1993) Principle of Unambiguous Binding. Similar to Müller, Zimmermann (1993) as well as Sternefeld (2006) suggest that the relating clause is a DP-adjunct, (6b). Sudhoff (2003) regards his es-correlate to be a determiner whose complement is the relating clause, (6c).

(6) a. $\quad \ldots\left\{\left\{_{\mathrm{NP}}\left[{ }_{\mathrm{N}} e s\right] \mathrm{CP}\right\} \ldots\right.$

b. $\quad \ldots\left\{\left\{_{\mathrm{DP}}\left[{ }_{\mathrm{DP}} e s\right] \mathrm{CP}\right\} \ldots\right.$

c. $\quad \cdots\left\{{ }_{\mathrm{DP}}\left[\mathrm{D}_{\mathrm{D}^{0}}\right.\right.$ es $\left.] \mathrm{CP}\right\} \ldots$

An analysis similar to (6c) is pursued by Hinterwimmer (2010). Analyzing English it-proforms, he even regards the proforms relating to an if- or whether-clause as determiners. His approach is questioned in Schwabe (2015). Like FabriciusHansen (1980), she regards es-proforms and ProPPs in argument conditional constructions as referring pro-forms and the wenn-clauses as TP-adjuncts.

There is a widespread consensus in favor of the observation that the es-orrelate and its relating clause cannot co-occur in the middle field, (7).

(7) ${ }^{*}$ Max hat es, dass Lea krank war, bedauert. Max has it that Lea ill was regretted 
Sudhoff (2003) argues that the es-correlate would have to bear the accent of the complex constituent, but cannot do so because it cannot serve as a phonological head. As a consequence, the relating clause must move to the right, (8a), or the es does not appear phonologically, (8b).

(8) correlate $e s$
a. $\left[\mathrm{CP}_{1} \ldots\left\{\left\{_{\mathrm{DP}}\left[\mathrm{D}_{\mathrm{D}}\right.\right.\right.\right.$ es $\left.\left.] \mathrm{t}_{\mathrm{CP}_{2}}\right\} \ldots \mathrm{CP}_{2}\right]$
b. $\quad\left[\mathrm{CP}_{1} \cdots\left\{_{\mathrm{DP}}\left[\mathrm{D}^{0} \varnothing\right] \mathrm{CP}_{2}\right\} \ldots\right]$

According to Sudhoff, a complex DP with a phonologically non-realized D-head can be topicalized. The suggestion that topicalized clauses have empty heads is criticized by Schwabe (2013) and Frey (this volume).

As to the anaphoric pro-form $e s$ as in (4), Sudhoff suggests that it is a genuine proform that refers to a proposition denoted by a preceding clause. This proposition can be resumed by a right-dislocated clause as shown in (4) and (9).

(9) pro-form es

$$
\left[\mathrm{CP}_{1}\left[\mathrm{CP}_{1} \ldots e s_{2} \ldots\right] \mathrm{CP}_{2}\right]
$$

The uniform approaches differ with respect to the base-position of the related clause. Müller (1995), Sternefeld (2006), and Hinterwimmer (2010), on the one hand, advocate a movement approach where the es and the related clause first form a complex constituent in the middle field as in (6) and then are separated by movement of the related clause to the postfield. Haider (2010) and Schwabe (2013), on the other hand, argue for a non-movement analysis according to which the proform es is base-generated in the middle field and the related clause originates in the right periphery. As concerns the concrete structures, however, both differ. Schwabe assumes adjunction structures where the CP is adjoined to VP, (10a). Haider would assume a structure like the one in (10b), where the proform c-commands the associated CP.

$$
\begin{array}{ll}
\text { a. } & \ldots\left[\left[_{\mathrm{VP}}\left[{ }_{\mathrm{VP}} \ldots e s_{\mathrm{i}} \ldots\right] \mathrm{CP}_{\mathrm{i}}\right]\right. \\
\text { b. } & \ldots\left[\left[_{\mathrm{VP}} e s_{\mathrm{i}} \ldots\left[\mathrm{V}_{\mathrm{V}}, \mathrm{V}\left[\mathrm{CP}_{\mathrm{i}}\right]\right]\right]\right.
\end{array}
$$

Zifonun, Hoffmann \& Strecker (1997) do not use the generative framework and thus do not take movement into account at all.

\subsection{Prepositional correlates (ProPPs)}

Constructions with ProPPs have not been investigated as intensively as constructions with es-items. The reason for this might be that ProPPs only occur as oblique objects or as adverbials, whereas es-items have more functions - cf. Sudhoff (2003) and Zimmermann (this volume). 
As with respect to es-items, there are approaches that analyze all ProPPs in a uniform way and at least one approach that distinguishes between different types of ProPPs.

\subsubsection{Hybrid approaches}

According to Breindl (1989), there are ProPPs where the pronominal part is always prominently accented and thus cannot be reduced, $(11 \mathrm{a}, \mathrm{b}){ }^{2}$
a. Man erkennt einen Gourmet DAran, dass er genießt. one recognizes a gourmet ProPP that he enjoys 'You will recognize a real gourmet by the fact that he knows how to enjoy'.
b. ${ }^{*}$ Man erkennt einen Gourmet dran, dass er genießt.

Breindl calls these ProPPs Bezugselemente 'relating elements' and their relating clause Gliedteilsatz 'clause that is part of a constituent'. The relating element, she suggests, is referential and its relating clause is attributive. That is, it is part of a complex PP. Thus, Breindl's relating element syntactically resembles Sudhoff's (2003) correlate es, (8a). However both differ crucially in that Breindl's relating element is a referring proform whereas Sudhoff's correlate $e s$ is a determiner.

Breindl argues for a second ProPP-class. This class consists of ProPPs whose pronominal part can be deaccented and thus reduced, (12).

(12) Leas Chef hat darauf/drauf verzichtet, dass Max entlassen wird. Lea's boss has ProPP refrained that Max dismissed will be 'Lea's boss has refrained from dismissing Max.'

Breindl regards such ProPPs as Platzhalter 'placeholders'. A placeholder is said to be a dummy argument or expletive. Breindl calls its related clause a Gliedsatz 'constituent clause.' This clause is not part of the PP and is located in the postfield cf. also Reis (1997) and Axel-Tober (2012).

According to Breindl, a Platzhalter 'placeholder' as in (12) is only licensed by a particular verb class. Members of this class are, for instance, darauf ankommen 'depend on', darauf verzichten 'refrain', and sich darauf freuen 'look forward to'. Depending on the respective matrix predicate, a placeholder is obligatory or optional. Thus, the ProPP of darauf verzichten 'refrain' is obligatory whereas the ProPP of darum beneiden 'envy' is optional, (13a, b).

2. Frey (this volume) claims that the prepositional part of these ProPPs can also carry the main accent. The fact that the pronominal part cannot be reduced indicates that it bears a secondary accent if the prepositional part has the main accent. 
(13) a. Leas Chef hat ${ }^{*}$ (darauf) verzichtet, dass Max entlassen wird. Lea's boss has ProPP refrained that Max dismissed will be.

b. Max hat Frank (darum) beneidet, dass er reich ist. Max has Frank ProPP envied that he rich is 'Max envied Frank because he is rich.'

Predicates allowing relating elements but no placeholders are, for instance, daran erkennen 'recognize' (11a, b) or darauf basieren 'be based on'. As illustrated in (11b), their pronominal part cannot be reduced. Their ProPP is always obligatory.

In Breindl's approach, it is not clear whether a ProPP of a predicate that selects placeholders is a relating element when its relating clause is attached to it as in (14). It should be so because its pronominal or prepositional part is accented under these circumstances.

(14) Leas Chef hat Darauf/darauf, dass Max entlassen wird, verzichtet. Lea's boss has ProPP that Max dismissed will be refrained 'Lea's boss has refrained from dismissing Max.'

Provided placeholders can turn into relating elements as shown in (14), all P-object verbs license relating elements, but only a subclass of them selects placeholders. Predicates allowing relating elements also license anaphoric ProPPs, (15a, b).

$$
\begin{aligned}
& \text { a. Max sollte entlassen werden. } \\
& \text { Max should dismissed be } \\
& \text { 'Max was to be dismissed.' } \\
& \text { Sein Chef hat dann darauf/*drauf verzichtet. } \\
& \text { his boss has then ProPP refrained } \\
& \text { 'His boss has refrained from doing so.' } \\
& \text { b. Max trägt wieder den gelben Mantel. } \\
& \text { Max wears again the yellow coat } \\
& \text { Ich habe ihn daran } /^{*} \text { dran erkannt. } \\
& \text { I have him ProPP recognized } \\
& \text { 'I recognized him by it.' }
\end{aligned}
$$

\subsubsection{Uniform approaches}

Proponents of a uniform approach to ProPPs are, for instance, Müller (1995), Zifonun, Hoffmann \& Strecker (1997), Sternefeld (2006), Schwabe (2013), and Frey (this volume). Whereas Müller, Zifonun, Hoffmann \& Strecker, and Sternefeld do not take into account Breindl's empirical observations, Schwabe recognizes them partially, but advocates again a uniform approach where all ProPPs are proforms whose related clause is either adjoined to the PP or base-generated in a right-peripheral position - cf. (17) and (20) below. 


\subsubsection{Relationship between ProPPs and relating clauses}

Müller (1995), Sternefeld (2006), Axel-Tober (2012) as well as Schwabe (2013) analyze the ProPP and the relating clause as both being part of a complex PP. As to the internal structure of the complex PP, Müller (1995) suggests that the relating clause originates inside the NP projected by the pronoun $d a$. The pronoun $d a$ and the clause both occupy the Spec-position of the PP, (16). From this internal position the $\mathrm{CP}$ has to be extraposed to the right edge of the PP or of the clause, (14) and (12).

$$
{ }_{\mathrm{PP}}\left[_{\mathrm{NP}} d a\left[_{\mathrm{CP}} \text { dass Max entlassen wird }\right]\left[_{\mathrm{P}} \text { auf }\right]\right]
$$

Sternefeld (2006), Axel-Tober (2012), and Schwabe (2013) analyze the ProPP in a complex PP as the head of this PP and the related clause as an adjunct to this PP, (17).

$$
\left.{ }_{\mathrm{PP}}\left[{ }_{\mathrm{PP}} \text { darüber }\right] \mathrm{CP}\right]
$$

This complex PP can be located in the middle field and in the prefield, and it can be extraposed, (18a-c).

(18) a. Max' Chef hat ${ }_{\mathrm{PP}}\left[{ }_{\mathrm{PP}}\right.$ darauf $]\left[_{\mathrm{CP}}\right.$ dass Max entlassen wird $\left.]\right]$ verzichtet.

b. ${ }_{\mathrm{PP}}\left[{ }_{\mathrm{PP}}\right.$ Darauf] $\left[_{\mathrm{CP}}\right.$ dass Max entlassen wird $]$ hat Max' Chef verzichtet.

c. Max' Chef hat verzichtet $\left[_{\mathrm{PP}}[\mathrm{pP}\right.$ darauf $]\left[_{\mathrm{CP}}\right.$ dass Max entlassen wird $\left.]\right]$.

The CP in (18a) must not move to the left periphery because it is located in a PP-island. But it can be extraposed, (12) and (19).

$$
\ldots\left[{ }_{\mathrm{PP}}\left[{ }_{\mathrm{PP}} \text { darauf }\right] \mathrm{t}_{\mathrm{CP}}\right] \ldots \mathrm{CP}
$$

Haider (2010) and Schwabe (2013) assume a complex PP only if the ProPP and its related CP co-occur overtly as in (18a-c). In case of extraposition of the $\mathrm{CP}$ as in (12), they suggest that the ProPP is base-generated in the complement position and that the $\mathrm{CP}$ originates in a right-peripheral position, (20).

$$
\text { ... }\left[{ }_{\mathrm{PP}} \text { darauf }\right] \ldots \mathrm{CP}
$$

Missing ProPPs as in (13b) are regarded as elided by Müller, Sternefeld, and AxelTober. Schwabe (2013) argues against this approach by asking among other things for the conditions that determine ProPP-deletion.

\section{Longstanding questions and new contributions}

\subsection{Correlates and referential proforms}

The overview given in 2.1 and 2.2 of the German sentential proforms es and ProPP differentiated between hybrid and uniform approaches. As far as constructions 
with es-proforms are concerned, the hybrid approaches distinguish two estypes: placeholders or correlates, and anaphoric pro-forms. Axel-Tober, Holler and Krause (this volume) underpin the hybrid approach by presenting empirical data gained from psycholinguistic experiments and corpus research. Dutch data presented by Sudhoff (this volume) also serve to verify the hybrid approach. The hybrid approach gets additional support from prosodic evidence offered by Truckenbrodt (this volume). Frey (this volume) contributes new empirical data such as root phenomena that support a third es-type with respect to psych-verbs.

Schwabe (this volume) discusses German proforms which are related to conditional wenn-clauses that provide a propositional argument for the matrix predicate. She shows among other things that the referential es-proform that relates cataphorically to such an argument conditional can be focus marked, (21).

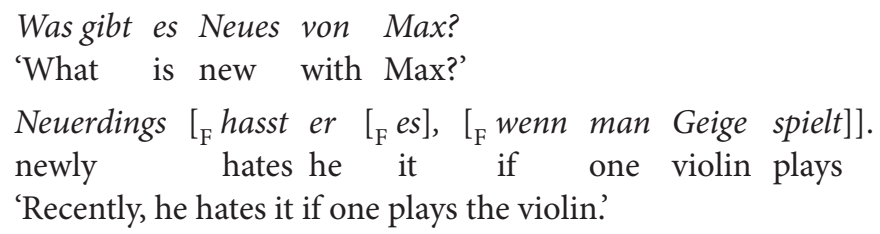

As to constructions with prepositional proforms, the overview given in 2.2 also presented hybrid and uniform approaches. Zimmermann (this volume), who regards ProPPs as suppletives of es-items and takes into account anaphoric and non-anaphoric ProPPs, distinguishes between anaphoric pro-forms and correlates. Unlike Breindl (1989) and like Schwabe (2013), Frey (this volume) presents arguments supporting a uniform approach. His approach also includes prepositional proforms relating to adverbial clauses.

\subsection{Complex DP- and PP-shells and the position of the related clause}

As shown in 2.2, it is reasonable to assume that ProPPs project a complex PP that contains the related clause if the proform and its related clause are adjacent, $(18 \mathrm{a}-\mathrm{c})$. It is still a matter of debate whether such a complex constituent is also necessary when the ProPP and its related clause are discontinuous, (12). It is also not uncontroversial whether es-correlates always project a complex DP. Frey, Sudhoff, Truckenbrodt, and Zimmermann (all this volume) suggest that the es-correlate projects a complex DP. As for ProPPs, Frey and Zimmermann (this volume) propose a similar analysis. The DP as well as the PP are base-generated in the canonical argument position, (22).
a. $\left[\mathrm{CP}_{1} \ldots\left[_{\mathrm{DP}}\left[\mathrm{DP}_{\mathrm{DP}}\right.\right.\right.$ es $\left.\left.] \mathrm{CP}_{2}\right] \mathrm{V} \ldots\right]$
Zimmermann
b. $\left[\left[_{\mathrm{CP}_{1}} \ldots\left[_{\mathrm{PP}}\left[{ }_{\mathrm{DP}}\left[{ }_{\mathrm{DP}} d a\right] \mathrm{CP}_{2}\right]\left[{ }_{\mathrm{P}} 0\right.\right.\right.\right.$ über $\left.\left.]\right] \mathrm{V} \ldots\right]$
c. $\left[{ }_{\mathrm{CP}_{1}} \ldots\left[_{\mathrm{DP}}\left[{ }_{\mathrm{D}}\right.\right.\right.$ es $\left.\left.\left.\mathrm{CP}_{2}\right]\right] \mathrm{V} \ldots\right]$
Zimmermann
Frey, Sudhoff 
While the related clause of the es-correlate extraposes obligatorily for phonological reasons, the related clause of the ProPP extraposes optionally, (23a, b). In the extraposed position, the related clause is integrated into the sentence structure in terms of Reis (1997) - cf. Truckenbrodt (this volume).

$$
\begin{array}{ll}
\text { a. } & {\left[{ }_{\mathrm{CP}_{1}} \ldots\left[_{\mathrm{DP}} \ldots \text { es } \ldots \mathrm{t}_{\mathrm{CP}_{2}}\right] \ldots \mathrm{CP}_{2}\right]} \\
\text { b. } & {\left[{ }_{\mathrm{CP}_{1}} \ldots\left[_{\mathrm{PP}}\left[{ }_{\mathrm{DP}}\left[{ }_{\mathrm{DP}} d a\right] \mathrm{t}_{\mathrm{CP}_{2}}\right]\left[{ }_{\mathrm{P}} 0 \ddot{u} b e r\right]\right] \ldots \mathrm{CP}_{2}\right]}
\end{array}
$$

The authors above regard an es-correlate as a means of supplying embedded propositions with a nominal support. Sudhoff and Zimmermann even assume that phonologically empty es-correlates fulfill this function. With regard to ProPPs like darüber ' $d a$-on' as in (22b), Zimmermann suggests that the nominal support is rendered by the pronominal part $d a$-. For her, this pronominal part is a kind of suppletive for the nominal es or das. Nolda (this volume), on the other hand, argues that the $d a$-element is an adverb that forms a prepositional adverb together with the preposition.

As shown in (22a, b), Zimmermann regards the relating clause of a correlate as an adjunct to a DP or PP. Sudhoff, who only discusses constructions with esitems, argues against the adjunct analysis, pointing to the problem that the related clause would not be accessible for subcategorization restrictions that are imposed on it by the matrix predicate $-\mathrm{cf}$. $(24)(=(11 \mathrm{a}, \mathrm{b})$ in Sudhoff this volume).

$$
\begin{aligned}
& \text { a. dass Peter }\left[{ }_{\mathrm{DP}} \text { es } \mathrm{t}_{\mathrm{CP}}\right]_{\mathrm{i}} \text { abwartet/hasst } \mathrm{t}_{\mathrm{i}} \text {, } \\
& \text { that Peter it } \text { awaits/hates } \\
& \left.{ }_{\mathrm{CP}} \text { dass Marie singt }\right] \\
& \text { that Marie sings } \\
& \text { b. dass Peter }\left[{ }_{\mathrm{DP}} \text { es } \mathrm{t}_{\mathrm{CP}}\right]_{\mathrm{i}} \text { abwartet/*hasst } \mathrm{t}_{\mathrm{i}} \text {, } \\
& \text { that Peter it awaits/hates } \\
& \left.{ }_{\mathrm{CP}} \text { ob Marie singt }\right] \\
& \text { whether Marie sings }
\end{aligned}
$$

Regarding anaphoric pro-forms, Frey, Sudhoff, Truckenbrodt, and Zimmermann (all this volume) assume that they are constituents that are located in the complement position and that their related clause is base-generated in a rightdislocated position, being thus not integrated into the sentence structure as in $(25 \mathrm{a}, \mathrm{b})$.

$$
\begin{array}{ll}
\text { a. } & {\left[{ } _ { \mathrm { CP } _ { 1 } } \ldots \left[{ }_{\mathrm{DP}}\right.\right. \text { es }} \\
\text { b. } & {\left[\mathrm{CP}_{\mathrm{CP}_{1}} \ldots\left[\mathrm{CP}_{\mathrm{PP}} \text { darüber }_{2}\right] \ldots\right] \mathrm{CP}_{2}}
\end{array}
$$

\subsection{Missing sentential proforms}

Likewise, the problem of missing propositional proforms is still under discussion. The problem arises with respect to predicates of the regret-type. 
As for Sudhoff (this volume), he advocates a phonologically empty es-determiner in a complex DP, (26a). As shown in (26b), Zimmermann (this volume) follows his suggestion, but unlike Sudhoff, she regards the missing correlate as an empty DP.

(26) Max hat bedauert, dass Lea krank war.

Max has regretted that Lea ill was

'Max has regretted that Lea was ill.'

a. $\left[\mathrm{CP}_{1} \ldots\left[{ }_{\mathrm{DP}}\left[\mathrm{D}_{\mathrm{D}}, \varnothing \mathrm{t}_{\mathrm{CP}_{2}}\right]\right] \ldots \mathrm{CP}_{2}\right]$

b. $\left[{ }_{\mathrm{CP}} \cdots\left[_{\mathrm{DP}}\left[\mathrm{DP}_{\mathrm{DP}} \varnothing\right] \mathrm{t}_{\mathrm{CP}_{2}}\right] \ldots \mathrm{CP}_{2}\right]$

Frey (this volume) questions this approach. He points to the observation that the head of a complex DP or PP must be accented if it forms a constituent together with its related clause and argues that Sudhoff's and Zimmermann's empty head approach will run into problems if the DP is topicalized.

Regarding argument conditionals in the postfield that exhibit an optional proform as shown in (1b), Schwabe (this volume) suggests that the missing proform is a phonologically covert pro, (27). The licensing conditions of this covert proform differ from those of the overt one, though.

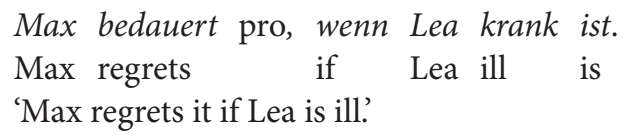

\subsection{Influence of sentential proforms on the sentence meaning}

Whereas most of the authors mentioned in 2.1 do not take into account the semantic impact sentential proforms may have on the sentence meaning, Sudhoff (2003) as well as Schwabe and Fittler (2014) consider the correlate es to trigger factivity. Frey (this volume) agrees with Sudhoff in this respect. He proposes that an escorrelate existentially binds the eventuality variable of the dependent clause. Zimmermann (this volume), however, assumes that predicates like bedauern 'regret' or stören 'disturb' are factive in all contexts. For her, the es-correlate does not contribute to the factive interpretation, but stresses it. As regards anaphoric es-pro-forms, she proposes that they mark givenness.

As concerns non-anaphoric proforms in constructions with argument conditionals, Schwabe (this volume) does not see an interpretational difference between constructions with overt and covert proforms, (28).

(28) Max bedauert es/pro, wenn Lea krank ist.

Max regrets it if Lea ill is

'Max regrets it if Lea is ill.' 
She suggests that the factive interpretation of the proposition the proform refers to is triggered by the potential factive meaning of the matrix predicate and the implication structure indicated by the conditional.

\subsection{Difference between es- and das-proforms}

It is commonly claimed that das, like es, can be associated with a dass-clause in the right periphery. The question arises whether the distinction between nonanaphoric correlate es and anaphoric pro-form also holds with respect to das. As observed by Pütz $\left(1986^{2}\right)$, das cannot relate to a non-given proposition, (29a, b).

(29) a. What's new? What happened?

Max hat es ${ }^{*}$ das bedauert, dass Lea krank war.

Max has it regretted that Lea ill was

'Max has regretted it/*that Lea is ill.'

b. Lea war krank und Max hat es/das bedauert, dass sie krank war.

Axel-Tober, Holler and Krause (this volume) provide empirical evidence that seems to confirm this observation. Frey and Sudhoff (both this volume) also regard das to be exclusively an anaphoric pronoun. Zimmermann (this volume) regards das as a suppletive of es. Like the authors mentioned above, she suggests that there exist anaphoric es- and das-pro-forms but no cataphoric das-correlates.

\subsection{Proforms and corresponding complex DPs}

Complex DPs or PPs consisting of a correlate and a relating clause can be compared with a lexical contentful DP that is specified by a relating clause. Zimmermann (this volume) discusses constructions where the correlate es is replaced by the DP die Tatsache 'the fact'. This DP is possible in the context of a potentially factive predicate, (30).

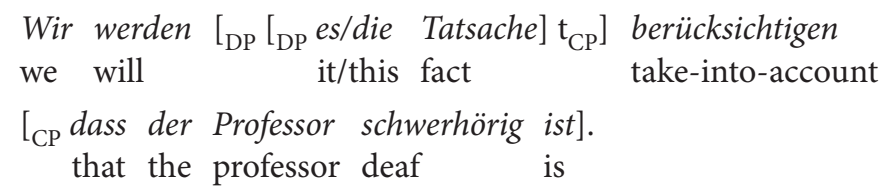

Zimmermann shows how the related clause combines semantically with the DP die Tatsache, a correlative noun in her terms.

\subsection{Lexical entries for sentential proforms}

If one is interested in the syntactic and semantic derivation of a complex construction with sentential proforms, one has to give one's opinion with respect to the 
lexical properties of these proforms. Zimmermann (this volume) provides exhaustive lexical entries for es-items including anaphoric es-pro-forms and es-correlates as well as their suppletive forms. The latter include das, dessen, dem, and da- as in darauf and damit.

As for prepositional sentential proforms, Nolda regards them as prepositional adverbials. As far as the prepositional adverb darunter ' $d a$-under' is concerned, he defines several variants, each belonging to one polysemous lexicological word. The choice of the respective variant depends on semantic properties of the matrix predicate. Two variants relate to propositions. For instance, the predicate sich etwas darunter vorstellen 'imagine what sth. is about' relates a thought content to a proposition specifying it and the verb darunter leiden 'suffer from sth.' relates the cause of a distress to an individual.

\subsection{Crosslinguistic variation}

This volume mainly focuses on German sentential correlates. However, Sudhoff (this volume) also refers to Dutch and shows that Dutch behaves very similarly to German. According to him, the Dutch het can occur in a focus domain if it co-occurs with a factive predicate like betreuren 'regret'. Then, it is a correlate in his terms. If het shows up with a non-factive predicate like zeggen 'say', it is an anaphoric proform. The volume also contains a study on Hungarian. As shown by Brandtler \& Molnár (this volume), Hungarian exhibits a sentential proform, the proform azt, which at first glance seems to be similar to German es or Dutch het. However, in contrast to the German and Dutch proforms, cataphoric azt can co-occur with an assertive predicate like say in one focus domain, but it cannot do so with a factive predicate like regret, $(31 \mathrm{a}, \mathrm{b})$.
a. Péter (azt) mondta, hogy gyakran találkoznak munka után. Peter it.ACC said.3sg that often gather.3PL up work after 'Peter said that they often meet up after work.'
b. Péter ( $\left.{ }^{*} a z t\right)$ bánja, hogy elfogadta a meghívást. Peter it.ACC regret.3sg that accept.PAST.3sg the invitation.ACC 'Peter regrets that he accepted the invitation.'

Brandtler \& Molnár present a theory where the insertion of the cataphoric azt depends on an edge-feature in C, that is, on the existence of SpecCP. Rendering the semantic content of the Hungarian edge-feature in terms of predicationality, they explain the contrast between constructions with a predicational say-predicate and cataphoric azt like (31a) and constructions with a non-predicational regretpredicate like (31b). Brandtler \& Molnár regard the anaphoric azt as not being restricted in this way. It originates in the main clause in postverbal position, 
forming a DP together with the complement clause. This complex DP may remain in situ or can be topicalized, (32).

Azt/AzT, hogy gyakran talákoznak munka után, MÁR mondta. it.ACC that often gather.3PL work after already said.3sG 'He has already said that they often meet up after work'

\section{The chapters}

This volume documents the achievements of linguistic investigation into the syntactic and semantic relationship between sentential proforms and their related clauses as well as into the lexical properties of the respective proforms. It discusses the syntactic properties of the different sentential proform constructions and shows that the relationship between sentential proforms and their related clauses is determined by properties of the matrix predicates as well as of the sentential proforms, that is, by the lexicon. It demonstrates that the very choice of a proform construction has strong effects on the information structural and phonological properties of the sentence containing it. Thus, this book aims to contribute to a better understanding of these interactions and to spell out the rules and conditions that define the complex relationship between a given sentential proform and its related clauses and its effects on grammar. To do this, it is essential to investigate the syntax, phonology, and semantics of sentential proform constructions and to provide empirical and experimental support for the theoretical claims.

The volume is structured as follows. It starts with papers supporting the hybrid approach discussed above. Sudhoff's paper, which, departing from Sudhoff (2003), distinguishes between correlate es and pro-form es, is virtually the reference paper for several contributions of this volume. It is followed by Axel-Tober, Holler and Krause's paper on German es and das, which gives experimental and empirical support for Sudhoff's analysis. Then, Frey's contribution gives additional support to Sudhoff's partition with a collection of syntactic tests. He extends the partition by including prepositional proforms and establishing a third es-type. Subsequently, Truckenbrodt's paper reinforces the distinction between the correlate and pro-form constructions by prosodic means. Truckenbrodt's contribution is followed by Zimmermann's article, which aims to integrate the major syntactic, prosodic, and semantic findings by defining a lexical entry for each proform type. Such an entry contains prosodic, syntactic, and semantic information. The second part of the volume consists of papers that are dedicated to special issues of sentential proform constructions. Nolda's article focuses on lexical properties of a particular prepositional proform, darunter 'there under'. 
Schwabe's paper discusses proforms that are not related to genuine complement clauses but to conditionals. And, finally, Brandtler and Molnár discuss the Hungarian proform azt, which seems similar to German $e s$ at first glance, but actually differs from it crucially.

\subsection{Theoretical and empirical arguments in favor of the hybrid approach}

\section{Stefan Sudhoff: Correlates of object clauses in German and Dutch}

The paper by Sudhoff develops the seminal Chapter 3 of Sudhoff (2003). The central observation, set up by Pütz $\left(1986^{2}\right)$ and made precise in Sudhoff (2003), is that in German there are two types of matrix predicates taking an object clause. One of them, the bedauern-type ('regret'-type), is compatible with correlate es; the other one, the behaupten-type ('say'-type), is incompatible with correlate es. Dutch shows a corresponding distinction between the two verb classes. Sudhoff argues that the German correlate es is the head of an argument DP and takes the embedded clause as its complement. Extraposition of the embedded clause is enforced by the phonological properties of es. Correlate es has to be rigorously distinguished from the anaphoric es, the latter being the only option for the construction with a verb of the 'say'-type, and a further option for the construction with a verb of the 'regret'-type. With constructions with anaphoric es, the subordinated clause is optional and, if present, is right-dislocated.

This basic distinction between the two types of matrix predicates taking an object, which Sudhoff (2003, this volume) clearly establishes, is taken up by different authors of the present volume.

Katrin Axel-Tober, Anke Holler \& Helena Krause: Correlative es vs. das in German: An empirical perspective

In their contribution Axel-Tober, Holler and Krause provide evidence for offline and online processing differences for the proforms das and es. They develop and apply two tests: a relatively simple acceptability test and a more sophisticated self-paced reading test. Both experiments lead them to claim that das can only be used as an anaphoric pro-form and not as a placeholder (in the sense of Pütz $\left(1986^{2}\right)$ or Sudhoff (2003; see also this volume)). Es behaves differently in not imposing requirements on the linguistic (preceding) context. Axel-Tober, Holler and Krause conclude that correlative es is homonymous between (i) a true placeholder (correlate es) and (ii) an anaphoric pro-form, and that das can only be used as an anaphoric pro-form. However, as shown by Pütz and Sudhoff, there is another decisive factor in addition to information structure: the verb class. Taking this into account, the authors provide further empirical evidence by conducting a corpus study targeting quantitative differences in the use of 
es with placeholder- vs. non-placeholder-taking verbs. Furthermore, an acceptability rating experiment reveals that (factive) verbs like bedauern 'to regret' have to be distinguished from verbs of the type behaupten 'to claim' with respect to the selection of placeholders. Thus, the authors give for the first time vast empirical evidence for the distinctions stated in Pütz and elaborated in Sudhoff (2003, this volume).

Werner Frey: On properties differentiating constructions with inner-sentential proforms for clauses

Frey's contribution discusses five major constructions which in the literature are often put into the same basket under the name 'correlative construction.' The constructions in question are proform constructions with an object clause selected by a verb of the regret-class (i) or by a verb of the say-class (ii), and constructions with a prepositional object clause (iii), with an adverbial clause (iv), or with a subject clause and an experiencer-object verb (v). By showing that these constructions behave rather differently regarding six basic syntactic and interpretative properties, the paper makes clear that the constructions have to be carefully distinguished. For every construction the paper aims to characterize the proform's interpretative function and to analyse the syntactic relationship between the proform and the dependent clause. A major insight of the paper consists in establishing that one of the constructions collected under 'correlative constructions' - namely (v) - even has the proform and the dependent clause, albeit co-referential, as independently generated different arguments of its verb.

Hubert Truckenbrodt: Some distinctions in the right periphery of the German clause Truckenbrodt is interested in the prosodic characteristics of complex clauses where a sentential proform is linked to a right-peripheral CP. His main focus is on the distinction between right dislocation (RD) and so-called afterthought (AT) on the one hand and regular extraposition on the other. Truckenbrodt analyzes the former two operations (RD and AT) as cases of ellipsis of full clauses. He elaborates two crucial distinctions: One distinction is of prosodic nature, the other concerns the information structure. For both distinctions, extraposition turns out to be part of the clause to which it attaches, while $\mathrm{RD} /$ $\mathrm{AT}$ is not. In the prosody, the syntactic domain for which a sentence requires sentence stress includes the extraposed XP, as in [clause + XP]. With RD and $\mathrm{AT}$, the dislocated constituent is outside of this domain of sentence stress, so that the preceding clause requires sentence stress regardless of the dislocated constituent: [clause] + XP.

This way Truckenbrodt confirms the existence of genuine correlates: Under verbs like bedauern 'regret', a clause on the right may be represented by a 
pronominal correlate in the clause; accordingly it then acts as extraposed to the right, rather than right-dislocated. In the analysis of Sudhoff this is because the clause is extraposed from a DP headed by the correlate: ${ }_{\mathrm{DP}}$ es $\left.\mathrm{CP}\right]$. A further case of apparent correlates, argued for by Frey (this volume), is also argued to be compatible with such an account.

Ilse Zimmermann: Phonological, morphosyntactic and semantic properties of es Like most contributors to this volume, Zimmermann also subscribes to the PützSudhoff-distinction between a pro-form and a correlate es. Taking seriously the lexical information of both es-types and their suppletive forms dessen, dem, and $d a(r)$ and das, which is only anaphoric, Zimmermann proposes that the pro-form as well as the correlate es are generalized quantifiers that existentially bind a propositional variable that is specified by its associate clause. She derives the crucial interpretational difference between both proform types from the syntactic position of the proform and its associate clause at LF. Adopting a cartographic model, she suggests that the related clause and the correlate es form a DP-shell which is nongiven and interpreted in SpecMoodP. The pro-form es, which is base-generated in the complement position, moves to SpecGivenP because it is given. In her contribution Zimmermann proposes a way of deriving the desired result compositionally by using the interaction of these contentful functional projections.

\subsection{Special topics of proform constructions}

Andreas Nolda: On the formation of prepositional adverbs in modern German: A case study on 'darunter'

Nolda's paper examines the inner structure and meaning of the prepositional proform darunter 'there under'. He argues that it is a prepositional adverb that consists of the adverb $d a$ and the preposition unter. Based on the variants of the preposition unter, he defines several variants of darunter. The intensions of the lexical meanings of the variants are gained compositionally. Thereby, the denotatum argument of the adverb-base is identified with the relatum argument of the corresponding prepositional base. It becomes clear from Nolda's typology that two of his eleven darunter-variants relate to propositions or concepts. One of them only shows up as an anaphorical pro-form. It is licensed by cognitive predicates like sich vorstellen 'imagine' or verstehen 'understand'. The other one can be used cataphorically. It is licensed by psych-verbs like ächzen 'moan', leiden 'suffer', and stöhnen 'groan', which relate a stimulus to an experiencer.

\section{Kerstin Schwabe: Sentential proforms and argument conditionals}

Whereas the papers introduced so far discuss proforms that represent the genuine complement of a proposition embedding predicate, that is, a subject or object, 
Schwabe's contribution examines sentential proforms that refer to propositional arguments that are provided by a wenn-clause. As proved by the existence of Onea's (2015) paper, it is not uncontroversial whether such a wenn-clause is an adverbial. However, following Fabricius-Hansen's (1980) adverbial hypothesis, Schwabe provides further arguments in favor of the adverbial approach. She shows how the complex meaning of constructions with argument conditionals and proforms referring to the proposition that is denoted by the wenn-clause is derived compositionally. And she proposes a zero sentential proform for a non-overt proform and defines its restrictions.

Johan Brandtler \& Valeria Molnár: Rethinking clausal asymmetries: Propositional pronoun insertion in Hungarian

Brandtler and Molnár broaden the Germanic perspective by introducing and analyzing a proform-clause relation in Hungarian. This non-Indo-European language features a construction which seems to be similar to the German(ic) structure, yet which is very different. The commonality is the basic characteristics that the pronominal element azt inside a matrix clause is anaphoric or associated with a subordinated dependent $\mathrm{CP}$ in the right periphery. However, non-anaphoric azt and Germanic correlates have different licensing conditions. The non-anaphoric proform azt is possible with assertive and non-assertive matrix predicates like 'say' and 'ask', but crucially it is not possible with factive predicates like 'regret' or 'know' (under standard, non narrow focus readings). The authors offer a strong modular approach arguing that the related clause of the cataphoric azt exhibits the syntactic edge-feature [+EF], which enables azt to be hosted in SpecC and then to move to SpecPred or SpecFoc of the matrix clause. They propose that in Hungarian, the edge-feature can be connected semantically to predicationality and pragmatically to Force and Focus.

\section{References}

Askedal, John Ole. 1985. Zur kontrastiven Analyse der deutschen Pronominalform es und ihrer Entsprechung det im Norwegischen. Deutsche Sprache 2: 107-136.

Axel-Tober, Katrin. 2012. (Nicht-)kanonische Nebensätze im Deutschen: synchrone und diachrone Aspekte [Linguistische Arbeiten 542]. Berlin: de Gruyter. doi: 10.1515/9783110276671

Bærentzen, Per. 1987. Die Spezialverwendungen des deutschen es und der dänischen Äquivalente det/der. Sprachwissenschaft 12: 341-380.

Breindl, Eva. 1989. Präpositionalobjekte und Präpositionalobjektsätze im Deutschen [Linguistische Arbeiten 220]. Berlin: Niemeyer. doi:10.1515/9783111358437

Büring, Daniel \& Hartmann, Katharina. 1995. All Right! In On Extraction and Extraposition in German [Linguistik Aktuell/Linguistics Today 11], Uli Lutz \& Jürgen Pafel (eds), 179-211. Amsterdam: John Benjamins. doi:10.1075/la.11.07bur 
Buscha, Joachim. 1972. Zur Darstellung des Pronomens "es" in einer deutschen Grammatik für Ausländer. Deutsch als Fremdsprache 9: 99-103.

Fabricius-Hansen, Cathrine. 1980. Sogenannte ergänzende wenn-Sätze. Ein Beispiel syntaktischsemantischer Argumentation. In Festschrift für Gunnar Bech: zum 60. Geburtstag am 23. März [Kopenhagener Beiträge zur germanistischen Linguistik, Sonderband 1], Gunnar Bech, Mogens Dyhr, Karl Hyldgaard-Jensen \& Jørgen Olsen (eds), 160-188. København: Institut for germansk filologi.

Haider, Hubert. 1994. Detached clauses - The later the deeper. Arbeitspapiere des Sonderforschungsbereichs 340: 41.

Haider, Hubert. 1995. Downright down to the right. In On Extraction and Extraposition in German [Linguistik Aktuell/Linguistics Today 11], Uli Lutz \& Jürgen Pafel (eds), 245-271. Amsterdam: John Benjamins. doi:10.1075/la.11.oghai

Haider, Hubert (2010): The Syntax of German [Cambridge Syntax Guides]. Cambridge: CUP. doi:10.1017/CBO9780511845314

Hinterwimmer, Stefan. 2010. When-clauses, factive verbs and correlates. In Language and Logos: Festschrift for Peter Staudacher on His 70th Birthday, Gisbert Fanselow \& Thomas Hanneforth (eds), 176-189. Berlin: Akademie-Verlag.

Huddleston, Rodney \& Pullum, Geoffrey K. 2002. The Cambridge Grammar of the English Language. Cambridge: CUP.

Müller, Gereon. 1995. On extraposition \& successive cyclicity. In On Extraction and Extraposition in German [Linguistik Aktuell/Linguistics Today 11], Uli Lutz \& Jürgen Pafel (eds), 213-243. Amsterdam: John Benjamins. doi:10.1075/la.11.08mul

Müller, Gereon \& Sternefeld, Wolfgang. 1993. Improper movement and unambiguous binding. Linguistic Inquiry 24: 461-507.

Onea, Edgar. 2015. Wenn-Sätze als propositionale Argumente. Zeitschrift für Sprachwissenschaft 34(1): 79-124. doi:10.1515/zfs-2015-0003

Pütz, Herbert. 1986² . Über die Syntax der Pronominalform >es< im modernen Deutsch, 2nd edn. Tübingen: Narr.

Reis, Marga. 1997. Zum syntaktischen Status unselbständiger Verbzweit-Sätze. In Sprache im Fokus, Christa Dürscheid, Karl Heinz Ramers \& Monika Schwarz (eds), 121-144. Tübingen: Niemeyer.

Sandberg, Bengt. 1998. Zum es bei transitiven Verben vor satzförmigem Akkusativobjekt. Tübingen: Narr.

Schwabe, Kerstin. 2013. Eine uniforme Analyse sententialer Proformen im Deutschen. Deutsche Sprache 41: 142-164.

Schwabe, Kerstin. 2015. On the licensing of argument conditionals. In Logic, Language and Computation. 10th International Tbilisi Symposium TbiLLC 2013, Martin Aher, Emil Jerabek, Daniel Hole \& Clemens Kupke (eds), 1-20. Berlin: Springer.

Schwabe, Kerstin \& Fittler, Robert. 2014. Über semantische Konsistenzbedingungen deutscher Matrixprädikate, Part 1. Sprachtheorie und Germanistische Linguistik 24(1): 45-75, Part 2. Sprachtheorie und Germanistische Linguistik 24(2): 123-150.

Schwarzschild, Roger. 1999. Givenness, AvoidF and other constraints on the placement of accent. Natural Language Semantics 7(2): 141-177. doi:10.1023/A:1008370902407

Sonnenberg, Bernhard. 1992. Korrelate im Deutschen. Beschreibung, Geschichte und Grammatiktheorie. Tübingen: Niemeyer. doi:10.1515/9783111377025

Sternefeld, Wolfgang. 2006. Syntax. Eine morphologisch motivierte generative Beschreibung des Deutschen. Tübingen: Stauffenburg. 
Sudhoff, Stefan. 2003. Argumentsätze und es-Korrelate. Zur syntaktischen Struktur von Nebensatzeinbettungen im Deutschen. Berlin: WVB.

Zifonun, Gisela, Hoffmann, Ludger \& Strecker, Bruno. 1997. Grammatik der Deutschen Sprache, Band II. Berlin: De Gruyter. doi:10.1515/9783111377025

Zimmermann, Ilse. 1983. Untersuchungen zum Verhältnis von Substantivgruppe und Nebensatz. In Untersuchungen zur Semantik [Studia Grammatica 22], Rudolf Rủžička \& Wolfgang Motsch (eds), 201-242. Berlin: Akademie-Verlag.

Zimmermann, Ilse. 1993. Zur Syntax und Semantik der Satzeinbettung. In Satz und Illokution [Linguistische Arbeiten 278], Inger Rosengren (ed), 1992/1993, Band 2, 231-251. Tübingen: Niemeyer.

Zimmermann, Ilse. 2002. Die Analysierbarkeit von Pronomen und Proadverbialia im Russischen. In Noun Phrases at the Phases [Sprache und Pragmatik 51], Christer Platzack (ed), 27-57. Lund: Germanistisches Institut der Universität Lund. 